\title{
A REVIEW OF THE TENDENCIES AND CHALLENGES IN THE EUROPEAN UNION LABOUR MARKET
}

\author{
Imola Cseh Papp * \\ Szent István University, Hungary, e-mail: papp.imola@gtk.szie.hu \\ Norbert Bozsik \\ Eszterházy Károly University, Hungary, e-mail: bozsik.norbert@uni-eszterhazy.hu \\ Erika Varga \\ Szent István University, Hungary, e-mail: varga.erika@gtk.szie.hu
}

Received July 2018; Accepted September 2018

\begin{abstract}
Purpose - The paper presents the phenomenon of the past decade (2008-2018) that shaped the labour market all over Europe and also points out the differences lying beneath with the changes generated in the post-crisis period. In the context of this study this literature review is intended to provide a theoretical background for the development of a piece of research revealing the new labour market phenomena.

Design/methodology/approach - The study first examines theoretical frameworks, solutions, and their practical operation through international experience.

Findings - The economic crisis, initially of financial nature, had its percussions felt on the state budget and went on to real economy. Its consequences were also felt on the labour market. According to global experience, modern economies and societies are facing several challenges including unemployment, labour shortage and underemployment at the same time, in spite of the fact that the level of employment has significantly been rising in the past few years.

Research limitations/implications - We applied an abductive approach. The reconstruction of past events is based on abduction, as we can deduce the events from their consequences and impacts on the present.

Practical implications - Both unemployment, labor shortages and underemployment result in unfavorable economic conditions in a country. It is of utmost importance to effectively address these phenomena in order to reduce and control their negative effects.

Originality/Value - Our study deals with the impact of employment on the labour market, the three key phenomena of the labor market: labour shortages, chnages in underemployment and international migration (labour migration) in European Union countries. Analysis is needed because conscious economic policy begins timely preparations for these changes.
\end{abstract}

Keywords: job vacancy, labour market, labour shortage, migration, underemployment.

Research type: research paper.

JEL classification: J24, J62.

\footnotetext{
* Corresponding author.
} 


\section{Introduction}

The global financial crisis, which was responsible for the second gravest recession in the economy of the European Union in the post-WWII period, started ten years ago. Although the crisis did not begin in Europe, it was the EU member states and their institutions that had to take firm measures to alleviate its impacts. The professional reaction had its effects felt as it is for five years now that the EU economy has continuously been improving. Unemployment has decreased to an extent that has not been experienced since 2008; banks are financially sound, more investments are triggered and state budget conditions are improving. The recent economic developments have given some ground for optimism but diminishing the aftermath of the crisis still takes some time.

As a consequence of the 2008 credit crunch the European Union fell to its gravest recession since its foundation, which affected individuals and member state economies alike. The economic crisis of the modern era differed from the previous ones from several aspects as profoundly it was also different from the classical economic theories. The professional debate on the nature of the crunch, its reasons and persons liable is still going on. What is known for sure is that the 2008 crisis was very novel and grave with some unforeseeable consequences. In spite of the fact that the economic downturn was triggered by the global financial crisis, the successive recession that affected several European countries aroused structural issues on productivity, budgetary imbalances and weak economic competitiveness. In the 24 European members of OECD GDP reached a high in 2008 , then it was continuously decreasing from the following year to a value that was only 0.5 higher than its original 2008 value by 2012.

Such a grave downturn in economic activity had serious consequences on the labour market, as well. After a decade of constant job creation several enterprises stopped operating or made part of their employees redundant, which significantly altered the ratio of the employed and unemployed. For the Europe-24 the employment rate of the working age (16-64) has continuously been rising since 1998 (it was 64.6\%) and by 2008 it reached a peak of 68.7 percent. Afterwards, in 2010 it decreased to 662 percent and in 2013 it stayed at 66.5 percent. In 2008 approximately 15.8 million people were unemployed in the Europe- 24 countries. This means an approximate rate of 6 percent, which increased to 10 percent by 2012. As job opportunities in the labour market became more restricted, employees also had lower expectations and even accepted jobs that previously had not met their requirements (underemployment). In many countries the uncertainties of employment resulted in changing full time jobs for part time ones involuntarily and also substituting labour contracts for an unlimited period for contracts for a limited period. Underemployment is also seen from the fact that the relatively skilled employees were compelled to accept jobs that required lower skills and qualification. As a result, the number of the employed 
Papp I.C., Bozsik N., Varga E., 2018, doi.org/10.33605/croma-022018-013

who were willing to work more hours increased from 9 percent to 11 percent in the Europe-24 countries between 2008 and 2012. This proportion means more than 3 million employees.

\section{Theoretical background}

However, the economic outlook has improved for the main export partners nowadays and due to the growing volume of orders more and more employees are necessary in the international private sector. As a consequence of the crisis, the bigger multinational companies curbed on production, which resulted in fewer orders from their suppliers (which had a negative impact on the number of employees), its reverse also holds true: the increasing production induced higher labour demand from the suppliers' side. Despite this, data reflect that although the European economy overcame the crisis and GDP started to rise, unemployment still affects many people. The number of underemployed was continuously increasing till 2013 due to labour hoarding but since then it has shown a decreasing tendency. According to some research (Dolphin et al., 2014) 60 percent of those underemployed stated that they would be willing to work more in their current job. To compare, it is only 8 percent who would do overtime to make up for the time lost, 10 percent would rather have a second job while 21 percent of the respondents would take any of the opportunities listed above. The current situation of the labour market can be characterised by the simultaneous presence of unemployment and labour shortage; so for some employees it is difficult to find a job meanwhile employers have difficulty in finding employees with the proper skills. Moreover, there are many underemployed, as well. As a result of mass education more and more graduates are entering the labour market, which means a fiercer competition (Czeglédi-Juhász, 2015).

Labour shortage is such a labour market phenomenon when the number of available jobs cannot be filled in due to the low number of employees. The most important difference between unemployment and underemployment is that while the first one refers to such an economic situation in which one is unable to find a job, the latter one is such a situation where job requirements are lower than the skills or qualification of the applicant. Underemployment means working fewer hours than in a full time job or below the qualification level for lower salary. Unemployment, labour shortage and underemployment result in unfavourable economic conditions in a country and they have to be treated effectively to reduce their negative impacts and control them. One of the tasks of this research into this topic is to clarify what factors and to what extent are responsible for the difficulties in recruitment that have been experienced by the economic players. 


\section{Research methodology}

The evolution of economic theories is characterised by having the experience in context and, in relation to it, explaining the reasons for the establishment of things. The study, on the basis of this train of thought, attempts to analyse the short-term labour market phenomena. At the end of the analysis the findings are rather only experiments to establish thoughts, but we hope to contribute to the academic and public discourse on the labour market.

We could not formulate precise hypotheses for our exploratory research, so we applied an abductive approach. The reconstruction of past events is based on abduction, as we can deduce the events from their consequences and impacts on the present. One of the tasks of scientific research is to clarify the factors and to what extent they are responsible for the difficulties experienced by economic players. The purpose of the literature review in this paper is to provide a theoretical background for the development of a research.

\section{Research results and findings}

\subsection{The definition and decisive factors of labour shortage}

In a market economy which is controlled by competition there can be situations when labour demand can hardly be met as it takes time for the wages and salaries to adapt to the scarcity of labour. That is why literature carefully applies the term 'labour shortage'. Instead, 'skill shortage' and 'talent shortage' is used. In real, it is the lack of competences that is emphasised. Moreover, job vacancies also inform us about the demand for labour which has not been met.

According to the OECD there is no standard definition for labour shortage. In the neoclassical approach financial mechanisms always lead to the equilibrium between labour demand and supply so there cannot be labour shortage. The temporary shortage of labour in an economy can only be explained by the fact that prices (wages) can adapt much slower. To conclude, the slow adaptation of wages can result in labour shortage (Köllő, Varga, 2017; Köllő et al., 2017).

Labour shortage is often identified as the inadequate number of talented employees. However, these terms have different meanings. While labour shortage covers a mainly quantitative gap in an economic sense, skills shortage rather reflects a qualitative deficiency. The statement according to which labour shortage includes all labour force whose presence would be necessary in the labour market, talent shortage is a smaller unit is true in many cases. To conclude, all talent shortages mean labour shortage in the economy but not all labour shortages will be talent shortage at the same time. The term talent shortage is used to describe a narrow layer of employees who can enhance their employers' competitiveness. As the roots of these shortages differ, special and targeted treatments are necessary. Labour shortage can be reduced by means of financial incentives both on 
macro-and microeconomic level while nonfinancial incentives are the best way to abolish talent shortage (Héder, 2017; Héder, Dajnoki, 2017).

It is difficult to measure labour shortage (Shah and Burke, 2003). A question can be raised when we can define the ratio of applicants and job vacancies as labour shortage. That is why most empirical studies contain employers' surveys to define labour shortage. On the one hand, this procedure raises a problem: the economic players are driven by their interests (companies have no risks in complaining about labour shortage and call for measures by the state such as decreasing VAT or contributions). On the other hand, half of the companies give an account of labour shortage but the ratio of job vacancies is much lower so even the lack of one employee can result in corporate labour shortage. Moreover, if the representatives of companies are asked about labour shortage they always mention, ,[...] such job vacancies where payment is equal to that of the engineers and researchers employed by the company." Frequently, they do not even think of pay rise as a possible remedy for lacking experts (Horbach, 2014). For a company offering jobs labour shortage always means that they cannot take on anyone for the vacant job with the salary offered. Labour shortage can only be interpreted together with the salary offered as these two factors are linked together. Although most publications on the topic tend to concentrate only on manpower shortage so consequently, reducing population, inadequately skilled workers and migration defined as the reasons for labour shortage are more emphasised and the significance of salary is pushed into the background (Fruchter and Sielewicz, 2017).

Labour shortage has other decisive factors in addition to salary adjustment mentioned earlier and higher demand for labour (Table 1) considering labour demand and supply (Dolphin et al., 2014; Horbach, 2014; Pettinger, 2017; Verdugo and Allègre, 2017).

Table 1. The decisive factors of labour shortage

\begin{tabular}{|c|c|}
\hline Labour supply & Labour demand \\
\hline Demographic changes (reducing population) & Innovation activities demanding new skills \\
Regional immobility & Very high recruitment costs \\
Wages and willingness for labour market & participation \\
Over-qualification & Differences in qualification due to structural changes \\
Work/life balance & Lack of measures on further training \\
Too low state investment in education & $\begin{array}{c}\text { National labour shortage: inexperienced graduates or } \\
\text { the elderly are not employed }\end{array}$ \\
\hline
\end{tabular}

Source: Horbach, 2014

\subsection{Factors of the demand side}

Regarding labour demand the innovation capacity of companies can be correlated with (qualified) labour shortage to a great extent as innovative enterprises require better qualified workforce than other companies. Highly qualified employees are present in the labour market in lower numbers than the unskilled workers. Furthermore, especially the new and rapidly developing 
industries such as the ones applying technologies of renewable energy sources may require new specific qualification profiles that may lead to scarcity in the labour market as only few have such professional qualification.

There are such areas in technology like environmental economics that require low labour efficiency and they mostly need unskilled and low paid labour force. The recycling activity of the company (with special regard to electronic waste) is only profitable if it supports disadvantaged employees or the long term unemployed supported by the state.

The labour demand curve's shift upward affects all industries to a great extent where new qualifications different from the ones before are necessary, such as renewable energy and its sector. Moreover, the expenditure of $R \& D$ is much higher than in any other technological areas so very few experts are likely to appear in these areas. That is why differences in qualification can mean a special problem for this sector.

While more and more jobs are available, it is more difficult to find the right candidates only by advertising. While in-company forms used to be efficient and most job vacancies did not even reach the open labour market, now the old methods are not adequate with the increase of jobs. Traditional advertisement is not effective as direct and almost tailor-made job offers reach the candidates in a greater number nowadays through social media. Experience shows that it takes a long time to fill in a job vacancy. Attracting talent, retaining the old workforce and ensuring such working conditions that would make employees committed to be more effective is a greater and greater challenge especially when there is a fiercer competition for the decreasing labour force of good quality. Recruitment and selection are not a one-time process in corporate life; rather, a continuous and conscious series of actions. It is time consuming and expensive to select the best candidates or applicants for a post. To achieve this job-person fit, it takes knowledge, properties, skills and abilities. The skills and knowledge can be divided into two parts: hard and soft elements. A lot of employers make a mistake when they only examine the hard ones and not enough attention is paid to other competences. The hard elements are easy to identify and know even from resumes. They include, for example, qualification, language knowledge, certificates of special professional qualification, work experience, internship and aptitude. Soft elements are more difficult to define as they range from characteristics to the way of thinking and attitudes. These are the competences that are not seen from resumes: abilities, knowledge level of intelligence, problem solving ability, way of thinking, emotional intelligence, interests, attitude, motivation, social competences etc.

Requirements and needs for the quality of labour force have also been changed and appreciated as quality work, the ability to adapt; independent learning and the development of generic competences are more and more important. Regardless jobs, employers require cooperative, 
Papp I.C., Bozsik N., Varga E., 2018, doi.org/10.33605/croma-022018-013

communicative, independent and creative labour force. At present a great part of graduates do not possess the skills and abilities required by the labour market. Such an education system is necessary in order to be able to ensure jobs to all career starters that reflect labour market needs and even so, it takes 10-15 years for the educational system to let the post-reform generation enter the labour market.

After the years spent in education a smooth transition to work may be the most important prerequisite of social integration. The quality of this process will define the social status and the labour market situation of the individual in the long term. One of the greatest barriers of the labour market participation of the young is few job opportunities that connect education and work. The shortage is especially striking with regard to study-related professional practice and internship, which could ease entering the labour market.

Employers are prejudiced against career starters to a great extent. Initial failures and joblessness can affect the young negatively as the series of failures can be rather discouraging. Furthermore, it also means burden on society as the jobless have to be supported and for the economy, lack of profit means loss that results from not using their labour force. Prejudice also exists against the elderly and their employment and generally, it can be stated that except certain jobs and managerial positions, this generation is discriminated.

\subsection{Factors of the supply side}

The process of ageing has accelerated and there has been a drastic reduction in the active, working age population, which is a cause for concern regarding economic competitiveness and the fragility of the social welfare systems. In aging societies there is a special problem that the number of the formerly active population going out of the labour market is greater that the new active population entering the labour market. This can lead to labour shortage as the residual labour demand of those going out of the market can be greater than the labour supply of the new, young cohorts available. This scarcity can even be made greater by the migration of the active aged population.

Migration can lead to structural defects in the labour market, but its effect depends on the structural compound of immigration and emigration and also the qualification and skills of the emigrants and those staying in the country. When the highly qualified part of the active population migrates, such as doctors or engineers, it is termed as brain drain. This phenomenon is more typical of the central part of Europe and in the Baltic countries due to the higher ratio of employees with higher education qualification than of Southern and Eastern Europe where the level of both education and qualification is lower. 
Papp I.C., Bozsik N., Varga E., 2018, doi.org/10.33605/croma-022018-013

The geographical position of certain companies may also result in labour shortage. On the one hand, if the costs of living are so high in the developed region that few can pay, or the infrastructure is inadequate, it can cause problems. On the other hand, it can result in lack of mobility that makes it impossible for the employee to find a potential job (e.g. lack of a bus service in some villages).

In the service sector or agriculture there are jobs that are difficult to fill in and it is not due to the wage cost; it is because the tasks are not attractive due to their monotonous nature, the necessary strenuous efforts or inclement weather conditions. The same applies to jobs with low social prestige.

In the public sector most salaries are fixed. Wages are fixed by the government and not the market forces. If the state cannot raise payment in the long term due to economic-political reasons, the highly qualified employees are attracted by the private sector.

The reason for labour shortage can also be low wages. Although there are labour reserves in each country, there are some who do not offer their labour force for such low wages. As a result, in everyday life the concept of labour shortage is manifested as a problem exclusively calling for state intervention to solve it and it is not a problem to be managed at corporate level. Obviously, the fact that many companies are not profitable enough to be able to provide a remarkable pay rise can also influence it.

It is necessary for the school to provide the students with adequate training, knowledge and professional skills for both economic and social considerations so that the young can meet the labour market requirements, the technical needs and their knowledge should be useable, modern and professional. The educational system still places the emphasis on the lexical knowledge of young people instead of improving their problem-solving ability.

In order to ensure adequate knowledge for the future generation in the labour market it is of vital importance that the university considers new tendencies when updating its teaching methods and content. Students should be taught how to use information and communication technologies to acquire the skills necessary for the more dynamic labour market.

In addition to professional knowledge education and schools, must convey important basic skills to the would-be employees so that they should be able to adapt and continuously develop in jobs that require either secondary or higher education qualification. Basically, it is not the most important thing to find out to what extent the professional structure of the graduates matches demand as they will basically spend 40-45 years in the labour market. The unforeseeable changes of technology will surely cease certain jobs and modify the content of other jobs. The future chances of vocational students will depend on their ability to retrain and follow the changes in their own 
Papp I.C., Bozsik N., Varga E., 2018, doi.org/10.33605/croma-022018-013

profession and adapt to the new requirements. All this makes employers realize the importance of lifelong learning, flexible adaptation to market requirements and the necessity of mobility.

The chances for finding a job, job-person fit and professional success are greater if individuals select a job of their interests and abilities. Career orientation plays a great role from this aspect. Good academic achievements, language knowledge and the general certificate of secondary education will further increase labour market chances.

Not all the factors listed above can be expressed numerically, so that is why the extent of labour shortage cannot be precisely defined. However, it is easier to assess job vacancies. According to Eurostat they are such unfilled jobs that are presently vacant or will be unfilled and for which the employer is actively seeking employees. In the 28 countries of the European Union the rate of job vacancies was 2 percent on the average. According to data on the third quarter (Figure 1) the rate of job vacancies was the biggest in the Czech Republic (4.1\%) and Belgium (3.6\%) while it was the lowest in Greece (0.5\%), Bulgaria $(0.8 \%)$, Spain $(0.8 \%)$ and Portugal $(0.9 \%)$. Germany (2.7\%), Austria (2.6\%), Great Britain (2.6\%), the Netherlands (2.5\%) and Hungary $(2.4 \%)$ are in the first third.

\subsection{The special features of underdevelopment}

The ILO defines underemployment as a labour market situation, where the employed are available and willing to work more hours than they are able to in their current situation. The definition was adopted in 1982 by the 13th ICLS and amended in 1998 by the 16th ICLS. Underemployment is one of the ILO's 20 Key Indicators of the Labour Market (KILM) for the monitoring and assessment of current labour market trends worldwide. According to the ILO, broadly interpreted underemployment can be used to describe any sort of unsatisfactory employment as perceived by the worker, such as insufficient hours, or insufficient compensation or use of one's skills. Underemployment has not been amongst the key labour market indicators in the EU, nor has Eurostat given specific attention to the concept of underemployment. However, in November 2011 Eurostat introduced three new indicators as 'halos' around unemployment. One of the indicators is 'underemployed part-time workers' (Haataja, 2011).

Underemployment has two types: visible and invisible.

Visible underemployment reflects the inadequacy of employment and includes the employees who work for fewer hours than typical in the industry despite the fact that they would be willing to work more. Due to economic constraints, their employers are unable to offer them full time jobs so they are forced to have part time or seasonal jobs. In statistics only the visible type of underemployment can be measured. 
Papp I.C., Bozsik N., Varga E., 2018, doi.org/10.33605/croma-022018-013

Invisible (or latent) underemployment refers to jobs in which the individuals' skills and competencies are not fully used. It is reflected in lower positions than their qualification, low productivity etc. among others. Such type of underemployment cannot be measured.

Underemployment causes disappointment for a lot of employees and makes several highly skilled individuals leave their home country to move abroad in order to find better jobs there. Both unemployment and underemployment are deformities of the labour market.

Underemployed workers can be divided into several categories. The most common types of underemployed workers are listed below:

- Skilled workers in low-paying jobs;

- Skilled workers in low-skill jobs;

- Part-time workers preferring full-time hours;

- Seasonal employees who would like to obtain full time jobs.

While underemployed workers are not necessarily unemployed workers, there is a certain category of unemployed worker that falls under the heading of underemployed. Unemployed workers who are currently looking for jobs may also be considered to be underemployed.

Underemployment has been attributed to adverse economic conditions, such as a recession. Underemployment is also caused when the supply of workers is greater than the demand for workers, or when there is a technological change. When there is a recession, unequal supply and demand, layoffs, or technological changes workers are displaced. Workers have to find different jobs, and this often leads to initially accepting low-paying, low-skilled, or part time work, to pay the bills (Haataja, 2011).

As a result of the 2008 credit crunch job insecurity was rising globally, which was reflected in the pressure of substituting full time jobs for part time ones and contracts of an unlimited period for limited ones. Policies of reducing working hours are generally introduced in the period of recession, which often does not meet employee preferences (Steiber, Haas, 2015). This coincided with the placement of relatively qualified employees in jobs that require lower qualification levels, which also refers to underdevelopment. The most important finding of the examination of Steiber and Haas (2015) was that the decreasing quality of job possibilities could not be traced down at all educational levels.

The number of the underemployed was relatively stable before the period of economic downturn but it increased by 47 percent between 2008 and 2012. There are a lot of reasons for the increasing tendency of underemployment including some positive and negative ones such as automation, a great number of graduates in higher education and the increasing rate of employing women even in jobs and positions reserved for men. The entitlements of welfare systems can also 
contribute to underemployment and can also encourage individuals to work lower hours even if they would like to be employed full time. In this case, however, above certain number of hours worked one cannot benefit from welfare allowances. For example, to be entitled to unemployment benefit in the United Kingdom, maximum 16 hours per week are allowed. Similar entitlement conditions are applied in Germany, as well.

According to Eurostat (2016) data 2.3 percent of employees had insecure jobs in the EU in 2016, which means that they had a contract for no longer than 3 months. Such short term contracts are typically made in agriculture, forestry and fisheries where 8.1 percent of employees are employed in such a form. In 20162.2 percent of the employees had short term contracts of seasonal nature in Hungary. Of the EU member countries Croatia has the most underemployed (8.4 percent). Contracts for a maximum of three months are frequent in France, Spain, Poland and Slovenia where 5 percent of the employees are concerned. Proportionally, the lowest level of underemployment can be found in Romania, Great Britain, the Czech Republic and Germany.

In 201614.2 percent of employees in the EU had temporary jobs while in Hungary this ratio was only 9.7 percent. Contracts for a limited period are the most frequent in Poland, Spain, Portugal, Croatia and the Netherlands. In Cyprus, Spain, Portugal, Hungary, Croatia, the Czech Republic, Belgium and Romania more than three-quarters of the employees with a contract for a limited period are employed in such a form because jobs with a contract for an unlimited period were not available.

In 2016 there were 9.481 million underemployed part-time workers in the EU-28. In addition to this, 8.782 million persons were available to work, but did not look for a job, and another 2.270 million persons were looking for jobs, without being able to start working in one within a short time period. These last two groups are normally jointly referred to as the potential additional labour force.

In total this means that in 2016 in the EU-28, 20.533 million persons had some resemblance to being unemployed, without fulfilling all the ILO criteria for being so. This is almost the same amount of persons who were unemployed according to the ILO criteria (20.908 million).

Underemployment has an impact on individual and household income, which can result in poverty for children and difficulties of social integration. Moreover, those concerned are very often not entitled to welfare allowances (such as pension, social security etc.) that are provided for full time employees. Unemployment on its own reduces the purchasing power of society while causing serious psychological problems to individuals. Milner et al. (2017) found linear correlation between the disadvantaged situation of the group and chances for insecure jobs. In real, it is also a good 
Papp I.C., Bozsik N., Varga E., 2018, doi.org/10.33605/croma-022018-013

thing if they have a legal contract for temporary work and not only the possibility of black work in the labour market.

Lack of development can also arise as one of the consequences as the underdeveloped have less chance for improving their professional knowledge. The offered training opportunities are of a relatively low level. The long term consequence of underdevelopment is much less chances of promotion or reaching a higher standard of living.

Today, we see automation and technology that take deeper roots in almost all the sectors of the economy. As the result, more jobs are been taken away than being created.

Underemployment leads to low wages which subsequently means a lower GDP than what the economy is capable of achieving. It also leads to wasting and underutilising human resources. It also hinders the career-goals and severely impacts the self-esteem of underemployed workers. Furthermore, it slows down the economic growth and the development of the country. Entrepreneurship is also a way to fight underemployment. The increasing number of start-ups is likely to contribute to job creation and help cope with underemployment.

Currently, approximately 48 percent of the graduates from higher education have jobs that do not require the skills and knowledge necessary for higher education degrees. In the past few years this gap between the trained and required skills and abilities has become wider as more qualified labour force have landed on jobs that require lower level of professional knowledge and consequently, pushed the lower qualified stratum out of the labour market. This has resulted in decreasing productivity due to reduced employment rate as the highly qualified employees are likely to be dissatisfied with compulsory jobs ( they would rather be bored and do not concentrate as much as their less qualified peers so they are not effective). Education and the inadequate exploitation of skills as well as human capital result in frustration and low working morale on both social (aggregate) and individual levels.

A further impact of underemployment is lower GDP on the macroeconomic level as it results in reduced individual income. Moreover, the partial use of human resources can hinder career orientation and damage the self-esteem of the underemployed.

The chances of survival for those concerned merely include self-training, obtaining information and possibly establishing an enterprise.

If full time positions could be offered to the underemployed, the number of the employed would not increase but economic performance would.

The rising underemployment level within the European Union suggests that there are huge hidden labour reserves: such economically inactive individuals who would be able to work but are 
Papp I.C., Bozsik N., Varga E., 2018, doi.org/10.33605/croma-022018-013

not looking for jobs; the unemployed and the underemployed who have a job but it is not satisfactory and finally those who are currently working abroad.

\subsection{Labour force mobility}

Movements beyond borders (within the borders of the European Union) are termed as international migration in the specialist literature. Currently, in the terminology of the European Union migration includes movements beyond the borders of integration.

According to this, a migrant is the person who does not possess the fourth freedom of the Treaty of Rome, i.e. free movement and free labour in the member states of the EU. The residence changes of citizens born within the area of the European Union beyond the national borders are termed as mobility (Dabasi-Halász, 2017).

For the citizens of the Eastern Central European countries emigration and working abroad became easier after their accession to the Union in 2004 and in 2007 in the case of Romania and Bulgaria, respectively. Previously, it was only after complicated bureaucratic processes that one could find a better paid job in the Western countries so only few were willing to undertake the hardships and expenses. Working abroad was not made easier even immediately after the EU accession as the old members could have the right to impose restrictions for seven years. It was the case in the most important target destinations of the Hungarian labour force. Germany, Austria and Switzerland had the longest restrictions on employing foreigners. The barriers were finally dismantled only in May 2011. However, Sweden, Ireland and the United Kingdom opened up their labour markets at the time of accession in May 2004. In 2006 Finland, Greece, Iceland, Italy, Portugal and Spain, in 2007 the Netherlands and Luxembourg, in 2008France, in 2009 Belgium, Denmark and Norway allowed the influx of employees. Language knowledge and cultural relationships had a great role in deciding which country the citizens of a nation wanted to work. Polish emigrants were mainly heading for England and Ireland. Initially, the Hungarians went to Germany and Austria. Regarding concrete figures most employees left Romania for Spain and Italy. Interesting economic changes have taken place since then.

In the countries of our region in 20160.3 percent of the population moved permanently to another Union member state while in the former EU-15 this ratio was 0.6 percent. One of the reasons for this is that in the latter ones working abroad has traditions and also language barriers are slighter. In Austria 17.4 percent of the total labour force are foreigners. Of the 615 thousand foreign employees 91 thousand are Germans, which means that every fourth employee comes from Germany. At the same time, however, every fiftieth employee is Hungarian citizen, which amounts to 71 thousand. 
Papp I.C., Bozsik N., Varga E., 2018, doi.org/10.33605/croma-022018-013

In the countries of Eastern Central Europe emigration seems to be more spectacular as it is basically unidirectional. On the one hand, much fewer people come to reside in our region from the Western states than vice versa. On the other hand, emigration was of a very low level in the region and gained momentum suddenly. In 2007 only 0.2 percent of the population moved to another country and by 2015 it increased to 0.5 percent. However, emigration cannot be examined in isolation and absolute value, as the process is mostly temporary, i.e. some individuals will return to their country of origin after a while. Considering this value net migration to foreign countries is decreasing in several countries nowadays.

Available statistics on migration distort reality in most cases. The reason of this is that citizens' movements can be monitored through changes in address or checking in and out of the social security system in most countries. If someone does not go to work but with the purpose of family reunion or works in the black economy, these data are excluded from these data. Many of these workers return home on a monthly basis; they do not rent apartments so they are not registered abroad (Ruhs, Vargas-Silva, 2016; Macro/Outlook report, July, 2017, CEE; Cerna, 2018).

While the countries of Western Europe cope with emigrants and crowds of refugees, Central and Eastern Europe has to face the challenges of emigration. The well qualified young people saying farewell to the Eastern countries leave behind a weakening economy and a decreasing population.

The ability of a country to attract and retain talent is an important factor that can influence human capital flight and brain drain World Economic Forum indicators (2017-18) show that countries' capacities to retain and attract talent are similar (Batsaikhan et al., 2018)

The emigration crisis of the region concerned was caused by stagnating post-communist economy and pro-migration union regulation. The single market does not only mean economic growth and welfare for all European countries. As borders opened for those accessing the Union in the 2000's waves of employees were heading to Germany, France and the United Kingdom. The original concept according to which Central and Eastern Europe will attract investors due to its low wages that will trigger economic growth seems to fail. The reason for this is that in these countries investors have to cope with significant labour shortage. The labour shortage due to the leave of guest workers scares foreign investors. According to IMF data the Central-Eastern European migration reduced the annual GDP of the countries in the region by 0.6-0.9 percent between 1999 and 2014. According to forecasts migration will reduce GDP per capita by 3-4 percent in Bulgaria, Romania and some Baltic countries. Of course, it will negatively affect the state budget. Most problems will be caused by pension, which amounts to half of the social expenditure in this region of Europe. 
Papp I.C., Bozsik N., Varga E., 2018, doi.org/10.33605/croma-022018-013

As a solution to this problem several countries launched 'Come home!' programmes, which were not effective in real.

Raising wages was not effective, either. In Bulgaria and the Baltic countries, for instance, in the past five years wages have surpassed the rate of improving productivity, which can affect their export competitiveness.

In other countries the response to the challenges of emigration was immigration. The population of Estonia increased in 2015 and 2016 after a decrease of the 1990's by receiving Ukrainian, Russian and Belorussian guest workers instead of the leaving ones. From the point of view the economy, however, an important issue is which layer of the labour force is departing and arriving. In Poland 400 thousand Ukrainian employees obtained a residential permit in 2015 who were employed in agriculture, construction and households as housekeepers while 30 percent of the departing Poles had higher education qualifications.

Due to Brexit, a huge wave of return migration may leave Great Britain for Central and Eastern Europe, which can increase the GD of these countries. A significant part of the former emigrants will head for the eastern part of Europe in the near future. The greatest impetus shall be given by the fact that before the Brexit the British pound is expected to weaken, which will devaluate the income and savings of those working in Great Britain. The return of the emigrants can rectify the shortage of skilled labour caused by their departure. This can boost investments in the region as it will join the economies of Western and Eastern Europe. The process will be fuelled by the fact that since the start of emigration the countries of Eastern and Central Europe have changed a lot. Many of them have improved legal environment, standard of education, the Western work culture has been adopted and occasionally, governance has also improved with weakening corruption and stronger political stability (Fruchter, Sielewicz, 2017).

The impacts of immigration on the labour market critically depend on the skills of migrants, the skills of existing workers, and the characteristics of the host economy. Research evidence on the labour market effects of immigration is thus always specific to time and place. Research does not find a significant impact of overall immigration on unemployment in the UK, but the evidence suggests that immigration from outside the EU could have a negative impact on the employment of UK-born workers, especially during an economic downturn (Ruhs, Vargas-Silva, 2016).

There are several misconceptions on immigration and emigration in the public thinking (Fleischer, 2017). One of them is that immigrants will push domestic labour force and cause unemployment. Another one is that immigrants can replace emigrants although it is not typical that a developing country could be recipient and sender at the same time. The general trend is that 
Papp I.C., Bozsik N., Varga E., 2018, doi.org/10.33605/croma-022018-013

countries with many departing citizens are not attractive for immigrants, either; and only few emigrate from countries that attract crowds of migrants.

\subsection{The migrant crisis}

The causes of the migration processes are long lasting no matter if they are demographic, climatic, economic or political issues. A dramatic change in labour force migration occurs only in the case of a natural disaster or war (Fleischer, 2017). The migration wave of the past few years differed from the previous ones as economic immigrants and refugees also arrived and these two groups are difficult to differentiate. According to Eurostat data most of them are males aged 18-34. This could be favourable for the economies of host countries but there are no exact statistical data available on the qualification of those arriving in the EU, which forecasts their difficulty in labour market integration. The economic success of immigration is also made more difficult by the growing social concerns of migration.

As for the long-term tasks, it is worth noting that both migrants and national citizens prefer the same economic circumstances (Fleischer, 2017).

\subsection{The current situation}

The current labour market situation can be best described by the simultaneous presence of unemployment and labour shortage, which means that the single employees cannot find jobs while employers also have difficulty in attracting employees with the right qualifications.

The Eurostat data disclosed in November 2017 reflect that since 2013 ten million jobs were created within the European Union so at present more than 235 million employees have a job. The labour market indicators improved in 2016 and the first half of 2017, which are a cause for some optimism when considering reaching the employment targets of the Europe 2020 strategy. After the crisis the rate of employment was rising most dynamically in 2016 (with 1 percent for those aged between 20 and 64) and it reached 72.2 percent in the first half of 2017, which is the highest ever in the European Union. The Europe 2020 strategy sets the target of a 75 percent employment rate. The highest annual increase of the employment rate (4.6 percent) was measured for the elderly (aged between 55 and 64).

Regarding unemployment rate there are significant differences between the member states. While Hungary, the United Kingdom, the Czech Republic, Malta or Germany has an unemployment rate of 5 percent or lower, it exceeds 20 percent in Greece and Spain. The seasonally adjusted unemployment rate decreased to 7.3 percent in November in the 28 member-states of the European Union, which is the lowest since October 2008. It means that there were 18.116 million unemployed 
Papp I.C., Bozsik N., Varga E., 2018, doi.org/10.33605/croma-022018-013

in the European Union and within it 14.263 million in the Eurozone. In all the member states of the European Union with disclosed and comparable data the rate of unemployment was lower than the previous year. The greatest annual decrease was recorded in Greece from 23.2 percent to 20.5 percent (September), Portugal from 10.5 percent to 8.2 percent, Croatia from 12.5 percent to 10.4 percent and Cyprus from 13.1 percent to 11.0 percent.

\section{Conclusions}

The research gave a thorough picture on the content of labour market phenomena based on international literature which are becoming more significant in practice, providing a suitable frame for the development of a piece of research that is based on future improvements.

It turned out only after the millennium in the labour market of the developed countries that companies have difficulty in finding skilled labour force. It is generally explained by labour shortage or shortage of skilled labourers and the effects of wages and corporate productivity are rarely counted in. It is a fact that the number of job vacancies has reached a record high in 20152016 and it will soon become so high that measures should be considered as soon as possible. That is why governments and enterprises are primarily concerned to attract most employees to the labour market. Thus, where are the hidden labour supplies? On the one hand, there are some economically active individuals who are able to work but are not looking for a job, or they are looking but at the moment they are not available (they could start later). On the other hand, every country has unemployed and underemployed who have a job, but it is not satisfactory and also those working abroad and the migrants. Nevertheless, it is the training and retraining of the labour force that show a way to the future. Industry 4.0 does not abolish rather redefine certain jobs and the necessary knowledge and skills will also be modified.

The analysis presented in the paper can be of great importance for the economic policy to consciously start preparing for the forthcoming changes ahead.

\section{References}

Batsaikhan, U., Darvas, Z., Raposo, I. G. (2018). People on the move: migration and mobility in the European Union. Bruegel Blueprint Series 28, 22 January 2018. 190 p.

Cerna, L. (2018). European High-Skilled Migration Policy. High-Skilled Migration: Drivers and Policies, Oxford University Press, p. 416. DOI: 10.1093/oso/9780198815273.001.0001

Czeglédi, Cs., Juhász, T. (2015). Mit várunk el a pályakezdőktől? Vélemények és szempontok a cégek oldaláról. Studia Mundi-Economica, 2 (3): 54-63.

Dabasi-Halász, Z. (2017). Bevezetés. Tér és Társadalom, 31(4): 3-7.

Dolphin, T., Gottfried, G., Raikes, L., Silim, A., Thompson, S. (2014). European Jobs and Skills - a Comprehensive Review 2014. Institute for Public Policy Research, p. 149. 
Fleischer, T. (2017). A migráció és társadalmi-gazdasági összefüggései: az MTA KRTK vándorszemináriuma. Tér és Társadalom, 31(1): 147-157.

Fruchter, D., Sielewicz, G. (2017). Labour shortages in Central and Eastern Europe countries: a growing concern for businesses, COFACE Economic Publications. May, 10 p. http://www.coface.com/News-Publications/Publications\#

Haataja, A., Kauhanen, M., Nätti, J. (2011). Underemployment and part-time work in the Nordic countries. Kela, Research Department. 84 p.

Héder, M., Dajnoki K. (2017): The Characteristics of International and Hungarian Talent Shortage. The Annals of The University of Oradea. XXIV(1): 621-636.

Héder, M., (2017). Munkaerő- vagy tehetséghiány? - Fogalmi különbségek feltárása a hatékony gyakorlati alkalmazás érdekében, International Journal of Engineering and Management Sciences, 2(4): 180-190. DOI: 10.21791/IJEMS.2017.4.15.

Horbach, J. (2014). Determinants of labour shortage: With particular focus on the German environmental sector (No. 22/2014). IAB-Discussion Paper. 22 p.

Eurostat (2016). EU Labour Market 2016. Available at: http://ec.europa.eu/eurostat/statisticsexplained/images/b/bb/Supplementary_indicators_to_unemployment\%2C_definition_and_characteristics_of_the_popul ation_Persons_aged_15-74\%2C_EU-28\%2C_annual_average\%2C_2016_\%28thousand_persons\%29.jpg

Köllő, J., Varga, J. (2017). Hiány és munkanélküliség. In. Munkaerőpiaci tükör. MTA Közgazdaság- és Regionális Tudományi Kutatóközpont Közgazdaság-tudományi Intézet, pp. 76-84.

Köllő, J., Nagy, D., Tóth, I. (2017). Mit értsünk „munkaerőhiányon”? In. Munkaerőpiaci tükör. MTA Közgazdaság- és Regionális Tudományi Kutatóközpont Közgazdaság-tudományi Intézet, pp 48-57.

Labour force "boomerang" - Colliers, Macro/Outlook report, July (2017), CEE, Available at: www.colliers.com/en-gb//.../CEE/Colliers_CEE_Boomerang-2017

Milner, A., King, T. L., LaMontagne, A. D., Aitken, Z., Petrie, D., Kavanagh, A. M. (2017). Underemployment and its impacts on mental health among those with disabilities: evidence from the HILDA cohort. J Epidemiol Community Health, jech-2017. http://dx.doi.org/10.1136/jech-2017-209800

Pettinger, T. (2017). Labour market shortage. Available at: https://www.economicshelp.org/blog/25536/labourmarkets/labour-shortages_

Ruhs, M., Vargas-Silva, C. (2016). The labour market effects of immigration. Migration Observatory Briefing, University of Oxford. Available at: http://www.migrationobservatory.ox.ac.uk/wp-content/uploads/2016/04/BriefingLabour_Market_Effects_of_Immigration.pdf

Shah, C., Burke, G. (2003). Skill shortages: concepts, measurement and implications. Monash University, Centre for the Economics of Education and Training, Working Paper, 52: 57.

Steiber, N., Haas, B. (2015). Overworked or underemployed? Actual and preferred household employment patterns in the context of the economic crisis. Vienna Institute of Demography Working Papers, 7: 21.

Verdugo, G., Allègre, G. (2017). Labour Force Participation and Job Polarization: Evidence from Europe during the Great Recession. Sciences PO OFCE Working Paper, 16: 39. 